\title{
THE ROLE AND IMPORTANCE OF COMPANY CRISIS DIAGNOSIS IN ANTI-CRISIS MANAGEMENT
}

\author{
Alona Klodane \\ Mg.soc.sc., lecturer, Rezekne Academy of Technologies, Rezekne, Latvia \\ e-mail: alona.klodane@ru.lv, phone: +371 22045698
}

\begin{abstract}
Nowadays, under a free market, crises at companies are a frequent phenomenon; however, anti-crisis management and related aspects are currently a little researched problem in Latvia. The research aim is to examine the nature of company crisis diagnosis and its role and importance in the anti-crisis management system. The research general tasks are: to describe the nature of company crisis diagnosis and review the scope, purpose and tasks of performing a diagnosis; to examine the role and importance of company crisis diagnoses in the company's anti-crisis management system. To achieve the aim, the following research methods were employed: monographic, descriptive, comparison as well as analysis. The present research performed an analysis of the definitions of company crisis diagnosis, an examination of the scope of purposes and tasks of performing a diagnosis; it defined the crisis diagnosis as the systematic application of several different (usually financial) models aimed at assessing the situation of the company, as well as the discovery of indications of a potential crisis. Also, the role and importance of diagnosis of a crisis at a company in its anti-crisis management were determined stressing the fact that crisis diagnostic is a source of high-quality and credible information about the real situation and the availability of resources as well as the basis for carrying out further anti-crisis activities and making decisions both during the process of crisis prevention and within the overall company management system.
\end{abstract}

Keywords: Anti-crisis management; company crisis; crisis diagnosis.

JEL code: $M 000$; $M 290$

\section{Introduction}

Nowadays, under a free market, crises at companies are a frequent phenomenon. The emergence of crises in the economy of a company is not always associated with the business performance of the legal entity itself: economic cycles and other macroeconomic relationships determine the emergence of a number of crises at the company. Therefore, a modern company management system has to be appropriate for discovering the indications of a potential crisis beforehand or providing the effective management of the current crisis as well as for protecting the company from negative consequences as much as possible. In this respect, foreign scientific practice in the fields of management and economics offers a wide range of research investigations dedicated to anti-crisis management - a separate kind of company management. Foreign research studies (Meište \& Jakštiene, 2015; Garškaite-Milvydiene, 2014; Altman \& Hotchkiss, 2006; 
Darling \& Kash, 1998; Коротков, 2003; Бланк, 2006; Авдошина, 2012; Решетникова, 2011) have focused on anti-crisis management from a number of perspectives: company management under a comprehensive economic crisis, a set of measures to be implemented in the insolvency situation of a company and particular activities to be done by an administrator during restructuring, reorganisation or bankruptcy.

In Latvia, a few researchers (Mogorite, Magidenko, et al., 2012; Didenko, Magidenko, et al., 2008; Didenko, Mogorite et al., 2012) have performed examinations of the principles of anti-crisis management and of overcoming a crisis. That is why anti-crisis management and related aspects are a little researched problem in Latvia.

Hypothesis: a company crisis diagnosis is an important initial element of anti-crisis management for the company.

The research aim is to examine the nature of company crisis diagnosis and its role and importance in the anti-crisis management system.

The research object is company crisis diagnoses. The research subject is the role and importance of company crisis diagnoses in the anti-crisis management system.

The specific research tasks are as follows:

- To describe the nature of company crisis diagnosis and review the scope, purpose and tasks of performing a diagnosis;

- To examine the role and importance of company crisis diagnoses in the company's anti-crisis management system;

- To elaborate conclusions on the key principles of company crisis diagnoses and their role and importance in the company's anticrisis management system based on the review of scientific and specific literature.

To achieve the aim, the following research methods were employed: monographic, descriptive, comparison as well as analysis. An analysis of the definitions of company crisis diagnosis was performed, the scope of purposes and tasks of performing a company crisis diagnosis was examined, the definition of the term crisis diagnosis was supplemented based on foreign research methodologies, the role and importance of performing company crisis diagnoses were identified as well as the most important conclusions were drawn by using the mentioned methods.

\section{Company crisis diagnosis, its purpose and main tasks}

To date, the problem of diagnosing a crisis at micro level (the level of a business entity) has been little researched in Latvia. However, a number of interpretations of company crisis diagnosis are available in the foreign scientific literature. The term diagnosis is defined as the revelation of 
nature and causes of a particular phenomenon; as the identification, description of a problem (Darling \& Kash, 1998); or as the identification of the symptoms or signals, which determine the existence of a problem (Smith, 1995). An examination of the object to be diagnosed aims to yield the diagnosis results, i.e. to make a conclusion on the state of the object diagnosed (Решетникова, 2011). The mentioned and similar explanations may be theoretically considered to be universal, and they may be employed in various fields, including economics.

The latest research studies (Sakalas \& Virbickaite, 2011; GarškaiteMilvydiene, 2014; Meište \& Jakštiene, 2015) define a crisis diagnosis as the application of several different (usually financial) models aimed at assessing the situation of the company, as well as the discovery of indications of a potential crisis. By defining this term in such a way, the object to be diagnosed is specified: a company and its financial situation. A number of researchers (Львова, 2015; Бурцева \& Жарких, 2012; Решетникова, 2011; Бланк, 2006) point that a company diagnosis is a process that takes place in a particular space and time and it is of systematic nature (Асаул \& Коротаева et al., 2007). For these reasons, it is advised to integrate the principle of regularity in the definitions of a company crisis diagnosis, placing focus on the systematic application of models aimed at assessing the situation of the company and the discovery of indications of the crisis.

Based on the diverse definitions of the term company crisis diagnosis, the scientific literature provides a number of definitions of the purpose of performing it. In general, the purpose of performing a diagnosis is defined as the necessity to identify the deviation of performance indicators from the standard (Решетникова, 2011) and to establish a diagnosis for the object examined or to give an assessment of the object's state as of the end date of a process (Коротков, 2003; Минаева \& Юткина, 2008; Курочкин, 2015 ) and for the future (Коротков, 2003; Минаева \& Юткина, 2008), as the results of the crisis diagnosis are often employed to forecast the company's future prospects (Баймахамбетова, 2010) as well as to simulate the potential scenarios of the crisis.

Detailing the definition leads to the purpose of performing a company crisis diagnosis - to assess the company's situation and to reveal and describe the indications and nature of a crisis beforehand (Баймахамбетова, 2010). Based on an examination of the nature of crisis diagnosis and the definitions of purposes of performing a diagnosis, one can find that the key purpose of performing the crisis diagnosis is to assess or diagnose the company's situation and to identify the indications and characteristics of a potential or the current crisis beforehand. 
In general, the tasks of performing a diagnosis may involve the identification of certain activities and their implementation aimed at improving the performance of all elements of the system (Коротков, 2003; Минаева \& Юткина, 2008; Курочкин, 2015). To provide effective business performance and in order not to lose a competitive advantage, every company has to persistently observe (critically) its current situation (Решетникова, 2011). Performing such a task can be provided by a correctly functioning system of crisis diagnosis.

\section{Company crisis diagnosis in the anti-crisis management system}

Anti-crisis management is "a process, which anticipates the danger of crisis, carries out an analysis of its symptoms, measures limiting the negative consequences of the crisis and uses its factors to continue the development process" (Krzakiewicz, 2008). Researchers emphasize the essence of anti-crisis management: its task is to avoid a crisis at a company or, in case it is present, to minimise the potential negative consequences of the crisis for the company's systems (Коротков, 2003; GarškaiteMilvydiene, 2014), including minimising the financial loss of the company. So, performing a crisis diagnosis, the purpose of which is to identify the indications of a potential crisis beforehand or reveal the characteristics of the current crisis, is a separate function of anti-crisis management and a specific stage (Баймахамбетова, 2010), which involves a number of gains (see Figure 1).

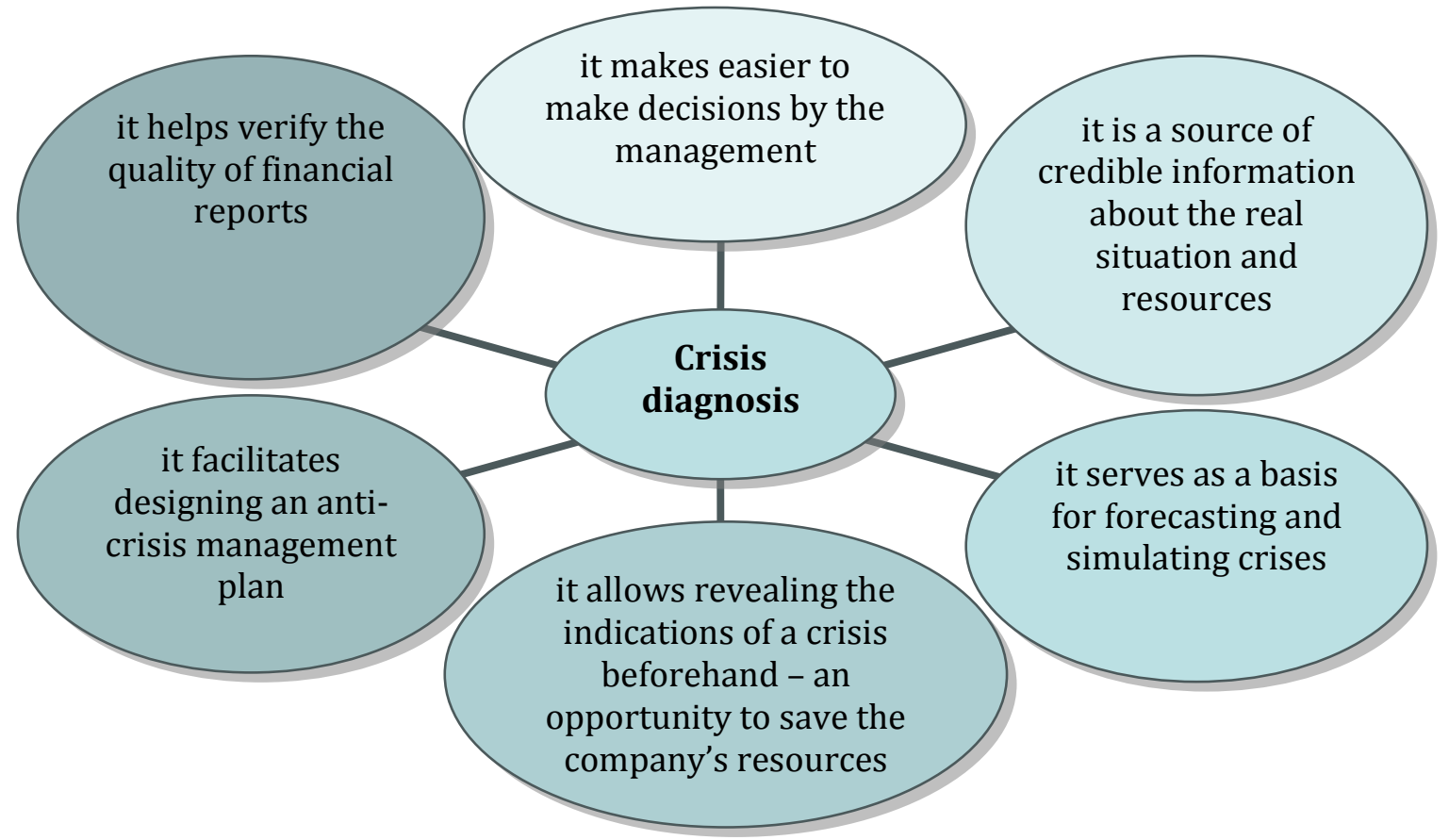

Figure 1. Gains from crisis diagnosis in the anti-crisis management system (created by author) 
Performing a crisis diagnosis plays an important role, and it may be called an example of a company's decision-making and information system for its management (Sakalas \& Virbickaite, 2011). When systematically assessing a company's situation and identifying the symptoms of a crisis, the company's managers and owners acquire high-quality and credible information about the company's real situation and opportunities at the particular stage of crisis (Балдин \& Передеряев et al., 2012). If employing a number of indicators, performing a crisis diagnosis provides and to some extent facilitates an analysis of a large amount of information (Sakalas \& Virbickaite, 2011).

Based on the result of performing a diagnosis, a company's managers get an opportunity to make prudent decisions regarding taking specific management measures and to design an adequate anti-crisis management plan (Sakalas \& Virbickaite, 2011; Балдин \& Передеряев et al., 2012), as well as to develop and correct the company's strategy and tactics according to the situation (Назаренко, 2011). "Diagnosing a crisis is important to identify its level of depth, what will lead to further decisions in selecting means and resources on crisis liquidation and restoring company performance or starting the bankruptcy process or event liquidation" (Sakalas \& Virbickaite, 2011; Meište \& Jakštiene, 2015). After summarising the opinions available in the scientific literature, one can conclude that a crisis diagnosis is a source of high-quality and credible information about a company's situation and resources and it serves as a basis for carrying out further anti-crisis activities and making decisions not only during the process of crisis prevention but also within the overall company management system.

Some researchers (Sakalas \& Virbickaite, 2011) point that the earlier the indications of a crisis are revealed, the more adequate anti-crisis (avoidance) measures can be taken and the greater opportunities to incur smaller losses are available for companies. For example, in the prodromal crisis phase, which some researchers (Mitroff et al., 1996; Fink, 2002; Paraskev, 2006; Meište \& Jakštiene, 2015) note as the first stage of crisis development, the probability of emergence of problems as well as of bankruptcy is very low because at this stage fluctuations in the performance of the company not always indicate a crisis (Meište \& Jakštiene, 2015), and by discovering crisis signals particularly in the prodromal crisis phase, the company can avoid significant losses, as in this case the company has an opportunity to identify the causes of a potential crisis, to design a plan of adequate anti-crisis activities and to avoid the crisis through effectively implementing the plan. Otherwise, "if the right moment is missed and situation is not assessed properly, a crisis can strike a company and its performance and management cannot avoid big losses" 
(Meište \& Jakštiene, 2015). At the next acute crisis stage it is impossible to recover all the loss (Darling \& Kash, 1998), and with the crisis becoming stronger, the company's losses increase, whereas its opportunities to stabilise the situation and regain the pre-crisis situation decline. By carrying out only crisis diagnosis activities when the indications of obvious problems appear, the probability of incurring greater losses considerably rises, which can lead to the deep insolvency of the company, its bankruptcy and the initiation of a liquidation procedure. That is why an early (timely) discovery of the indications of a crisis increases opportunities to overcome the crisis and reduces the probability of large losses in case the crisis develops. Performing a crisis diagnosis is one of the preventive measures in the anti-crisis management system.

However, it is important to note that a crisis diagnosis done at high quality and the timely identification of indications of a potential or the current crisis and the characteristics of the crisis that are objectively assessed, for example, the depth of the crisis, do not guarantee that the company's crisis is avoided completely. It is important to objectively assess the causes of the crisis, design an anti-crisis management plan according to the situation and prudently implement the plan's activities, mobilising the resources available to the company.

\section{Conclusions}

1. The latest research studies (Sakalas \& Virbickaite, 2011; GarškaiteMilvydiene, 2014; Meište \& Jakštiene, 2015) define a crisis diagnosis as the application of several different (usually financial) models aimed at assessing the situation of the company, as well as the discovery of indications of a potential crisis. If taking into consideration the fact that a company diagnosis is a process of systematic nature, which takes place in a particular space and time, it is advised to integrate the principle of regularity in the definitions of company crisis diagnosis (which is not specific to the definitions examined), putting focus on the systematic application of models aimed at assessing the situation of the company and the discovery of indications of the crisis.

2. Detailing the definition leads to the purpose of performing a company crisis diagnosis - to assess the company's situation and to reveal and describe the indications and nature of a crisis beforehand.

3. After summarising the opinions available in the scientific literature, one can conclude that a crisis diagnosis is a source of high-quality and credible information about a company's situation and resources and it serves as a basis for carrying out further anti-crisis activities and 
making decisions not only during the process of crisis prevention but also within the overall company management system.

4. An early (timely) discovery of the indications of a crisis increases opportunities to overcome the crisis and reduces the probability of large losses in case the crisis develops. Performing a crisis diagnosis is one of the preventive measures in the anti-crisis management system.

\section{References}

1. ALTMAN, E.I., HOTCHKISS, E. (2006). Corporate Financial Distress and Bankruptcy: Predict and Avoid Bankruptcy, Analyze and Invest in Distressed Debt. Third ed. New York: Wiley Finance.

2. DARLING, J.R.; KASH, T. (1998). Crisis Management: Prevention, Diagnosis and Intervention. Leadership \& Organization Development Journal, Vol. 19. p.179-186.

3. DIDENKO, K. MOGORITE, I. et al. (2012). Pretkrīzes vadišana uzṇēmuma krīzes dzīves cikla teorijā. Rìgas Tehniskās universitātes zinātnisko rakstu krājums. 2012. No. 22, 134. - 138. lpp.

4. DIDENKO, K., MAGIDENKO, A., MOGORITE, I. (2008). Crisis Influencing Factors and Root Causes. No: 49th International Scientific Conference of Riga Technical University "The Problems of Development of National Economy and Entrepreneurship": RTU Scientific Conference on Economics and Entrepreneurship (SCEE '2008): Conference Proceedings, Latvija, Rīga, 9.-13. oktobris, 2008. Rīga: RTU Izdevniecība. p.85.-89

5. FINK, S. (2002). Decision Making in Crisis: The Piper Alpha Disaster. Managing Crisis: Threats, Dilemmas, Opportunities, 6.

6. GARŠKAITE-MILVYDIENE, K. (2014). Anti-crisis management of enterprises and possibilities of overcoming their critical condition, Journal of Entrepreneurship and Sustainability Issues 1(4). p.187-203. DOI: http://dx.doi.org/10.9770/ jesi.2014.1.4(1)

7. KRZAKIEWICZ, K. (2008), Zarządzanie antykryzysowe w organizacji, Wyd. Akademii Ekonomicznej w Poznaniu, Poznań. (in Poland)

8. MEIŠTE, R., JAKŠTIENE, S. (2015). Crisis Diagnosis in Anti-Crisis Management Process in a Company. Institute of Economic Research Working Papers, No. 9/2015. Retrieved april 15, 2016, from http://dx.doi.org/10.12775/ OeC.2015.028

9. MITROFF, I.I, HARRINGTON, K.L., GAI, E. (1996). Thinking about the unthinkable. Across the Board, 33(8). p.44-48

10. MOGORITE, I., MAGIDENKO, A. et al. (2012). Basic aspects of crisis management methodology in small and medium size business. „Business and management 2012" 7th International Scientific Conference publication. 10-11Mai 2012. p11511161.

11. PARASKEV, A. (2006). Crisis Management or Crisis Response System? A complexity Science Approach to Organizational Crisis. Management Decision, 44(7). Retrieved april 15, 2016, from http://dx.doi.org/10.1108/ 00251740610680587

12. SAKALAS, A., VIRBICKAITE, R. (2011). Construct of the Model of Crisis Situation Diagnosis in a Company. Engineering Economics, Vol. 22(3). p.255-261. 
13. SMITH, R. (1995). Analysis of Earth-Moving Using Discrete-Event Simulation. Journal of Construction Engineering and Management, ASCE, 121. p.388-396.

14. АВДОШИНА, 3. А. (2012). Антикризисное управление: сущность, диагностика, методики. Планово-экономический отдел. № 07., 3-10 с.

15. АСАУЛ, А.Н., КОРОТАЕВА, Ю.В., КНЯЗЬ, И.П. (2007). Теория и практика принятия решений по выходу организаций из кризиса. СПб: АНО «ИПЭВ», 224 c.

16. БАЙМАХАМБЕТОВА, Г.И. (2010) Диагностика кризиса в антикризисном управлении. Вестник КазНУ, № 5 (81). 87-92 c. Retrieved april 15, 2016, from http://be.kaznu.kz/index.php/math/article/view/138/113

17. БАЛДИН К.В., ПЕРЕДЕРЯЕВ И.И., РУКОСУЕВ А.В., (2012). Антикризисное управление: макро- и микроуровень. 6-е изд. испр. Москва: Дашков и Ко, 268с.

18. БЛАНК, И. (2006). Антикризисное финансовое управление предприятием. Киев: ЭЛЬГА. 672 с.

19. БУРЦЕВА, М., ЖАРКИХ, Ю. (2012). Проблемы экспресс-диагностики кризисного состояния предприятия. Вестн. ОрелГИЭТ. №1(5). 51-56 с.

20. КОРОТКОВ, Е.М. (2003) Антикризисное управление. Москва: Инфра-М. 432с.

21. КУРОЧКИН, В.Н. (2015) Финансовый менеджмент в отрасли образования: у.п.. М.-Бердин: Директ-Медиа, 473 с.

22. ЛЬВОВА, Н.А. (2015) Финансовая диагностика предприятия. Монография. Под ред. В.В. Иванова. М.: Проспект. 301 с.

23. МИНАЕВА, Е.В., ЮТКИНА, О.В. (2008). Антикризисное управление, У/п пособие. - М.: МГУТУ. 54 с.

24. НАЗАРЕНКО, Е.А. (2011) Диагностика кризисных явлений в финансовохозяйственной деятельности промышленного предприятия. Вестник МГОУ, Серия “Экономика”, № 3/20114. 123-129 с. Retrieved april 17, 2016, from http://www.vestnik-mgou.ru/Articles/Doc/5753

25. РЕШЕТНИКОВА, Е.А. (2011). Теоретические основы диагностики кризисов в системе управления организацией. Вестник БИСТ, №. 3 (11), 103-110 с. 


\title{
UZŅĒMUMA KRĪZES DIAGNOSTIKAS LOMA UN NOZĪME PRETKRĪZES VADĪBAS SISTĒMĀ
}

\author{
Aḷona Klodāne \\ Mg.soc.sc., Rēzeknes Tehnoloǵiju akadēmija, lektore
}

\section{Kopsavilkums}

Mūsdienu brīvā tirgus apstākḷos krīzes uzṇēmumā ir bieža parādība, savukārt pretkrīzes vadība un ar to saistītie aspekti šobrīd paliek maz pētīts jautājums Latvijā. Pētījuma mērk,isis ir izpētīt uzṇēmuma krīzes diagnostiku, tās nozīmi un lomu pretkrīzes vadības sistēmā.

Pētījuma objekts - uzñēmuma krīzes diagnostika. Pētījuma priekšmets uzṇēmuma krīzes diagnostikas nozīme un loma pretkrīzes vadības sistēmā.

Pētijjuma uzdevumi ir sekojoši:

1. Izpētīt uzṇēmuma krīzes diagnostiku, apskatīt jēdziena saturu, mērḳi un uzdevumus;

2. Izpētīt uzṇēmuma krīzes diagnostikas lomu un nozīmi pretkrīzes vadības sistēmā;

3. Balstoties uz zinātniskās un nozares literatūras pētījuma rezultātiem, veikt secinājumus par uzṇēmuma krīzes diagnostikas pamatnostādnēm, tās lomu un nozīmi uzñēmuma pretkrīzes vadības sistēmā.

Izvirzītā mērḳa sasniegšanai tika izmantotas monogrāfiska jeb aprakstoša pētīšanas, salīdzināšanas, kā arī analīzes metodes. Pielietojot minētās metodes, tika veikta uzṇēmuma krīzes diagnostikas definējumu analīze, mērḳu un uzdevumu saturiskā izpēte; aktualizēta un noteikta uznēmuma krīzes diagnostikas loma un nozīme pretkrīzes vadības sistēmā, kā arī ir veikti šādi svarīgākie secinājumi.

Jaunākajos zinātniskajos pētījumos (Sakalas \& Virbickaite, 2011; GarškaiteMilvydiene, 2014; Meište \& Jakštiene, 2015) krīzes diagnostika tiek definēta kā vairāku atšķirīgu (parasti finanšu jomas) modeḷu pielietojums uzṇēmuma stāvokḷa novērtēšanai, kā arī iespējamās krīzes pazìmju atklāšanai. Apsverot faktu, ka uzṇēmuma diagnostika ir sistemātiska rakstura process, kas norisinās noteiktā telpā un laikā, tiek piedāvāts uzṇēmuma krīzes definējumos atzīmēt sistemātiskuma principu (ko neparedz izpētītie definējumi), liekot akcentu uz sistemātisku modeḷu pielietojumu uzṇēmuma stāvokḷa novērtēšanai un krīzes pazīmju atklāšanai.

Izejot no konkretizētā krīzes diagnostikas definējuma, tās mērḳis ir novērtēt uzṇēmuma stāvokli jeb veikt diagnozi un laicīgi identificēt iespējamās vai esošās krīzes pazimes un raksturlielumus.

Apkopojot vairākus zinātniskajā literatūrā izklāstītus viedokḷus, var secināt, ka krīzes diagnostika ir kvalitatīvās un ticamas informācijas avots par uzṇēmuma konkrēto situāciju un resursu esamību, kā arī pamats turpmāko pretkrīzes pasākumu veidošanai un lēmumu pieñemšanai ne tikai krīzes novēršanas procesā, bet arī vispārējā uzñēmuma vadības sistēmā. Savukārt agrīnā (savlaicīga) krīzes pazìmju diagnosticēšana palielina krīzes pārvarēšanas iespējas un samazina uzṇēmuma lielo zaudējumu varbūtību, tā krīzes attīstības gadījumā.

Atslēgas vārdi: krīzes diagnostika; pretkrīzes vadība; uzṇēmuma krīze. 